\title{
TINJAUAN YURIDIS TERHADAP PEMBIAYAAN MODAL VENTURA SYARI'AH TERHADAP USAHA MIKRO KECIL DAN MENENGAH (UMKM) DENGAN SISTEM PERHITUNGAN PROFIT SHARING
}

\author{
Oleh : \\ Edy Nurcahyo \\ Dosen Fakultas Hukum \\ Universitas Muhammadiyah Buton \\ E-mail: cahyonur3dy@gmail.com
}

\begin{abstract}
The purpose of this research is to describe a legal review against syariah venture capital financing which given to business partner which in the form of micro business, small business, and medium enterprises with profit sharing. This research method is normative legal research. The main data source which is used is the literature. Researcher uses a conceptual approach because of adapts to the legal material under study, then it analyzed by qualitative analysis. The result of research shows that syariah venture capital financing have gined legal protection from positif law in Indonesia for doing financing based on prinsip's profit sharing. Every business operation of Syariah Venture Capital Financing and Syariah Business Unit must fulfill the principles of justice, equilibrium, benefit, and univeralism.
\end{abstract}

Keywords: Legal Review, Financing, Syariah Venture Capital, Profit Sharing

\section{A. PENDAHULUAN.}

Usaha Mikro, Kecil, dan Menengah (UMKM) memiliki peranan yang luar biasa bagi kemajuan ekonomi Indonesia. Apabila UMKM Indonesia dapat tumbuh dan berkembang, maka kemungkinan akan memperkuat perekonomian Indonesia. Namun, UMKM memiliki kelemahan dalam kemampuan manajemen dan akses untuk mendapatkan modal, karena untuk mendapatkan kredit dari perbankan harus menyertakan jaminan (collateral).

Keberadaan Pembiayaan Modal Ventura di Indonesia menjadi alternatif sumber pembiayaan bagi dunia usaha khususnya UMKM. Menurut UU No. 20 tahun 2008 Tentang UMKM, UMKM memiliki akses untuk bermitra dengan Perusahaan Modal Ventura.

Salah satu karakteristik pembiayaan modal ventura adalah pembiayaan dengan berisiko tinggi (high risk) karena tidak didukung dengan jaminan (collateral) (Sunaryo, 2008: 26). Konsep tersebut memudahkan UMKM untuk mendapatkan pembiayaan dari Modal Ventura. 
Seiring dengan perkembangan dunia usaha, konsep ekonomi islam turut mewarnai perkembangan ekonomi di tanah air. Dalam dunia perbangkan banyak mengembangkan konsep perbangkan ekonomi islam (syariah). Bahkan konsep ekonomi islam dikembangkan dan diterapkan di lembaga keuangan non-perbankan, termasuk ke dalam pola pembiayaan modal ventura.

Sejak awal berdirinya modal ventura memiliki tiga pola hubungan hukum, yaitu peryertaan saham (equity participation), penyertaan melalui pembelian obligasi konversi (quasi equity participation), dan pembiayaan berdasarkan pembagian hasil usaha (Profit Sharing). Dari ketiga pola hubungan tersebut yang paling sesuai dengan karakteristik UMKM adalah pembiayaan berdasarkan pembagian hasil usaha (profit sharing). Yang menjadi problematik adalah apakah pembiayaan modal ventura konvensional khususnya pembiayaan modal ventura dengan profit sharing dapat diterapkan menjadi pembiayaan modal ventura syari'ah?, hal itu perlu dianalisis dengan pendekatan konseptual ditinjauan dari hukum islam dan hukum positif. Pembiayaan modal ventura dengan pola bagi hasil perlu ditinjau berdasarkan hukum Islam dan ditemukan perlindungan hukumnya dari sisi hukum positif. Oleh karena itu peneliti memilih judul "Tinjauan Yuridis terhadap Pembiayaan Modal Ventura Syari'ah terhadap Usaha Mikro, Kecil, dan Menengah (UMKM) dengan sistem perhitungan profit sharing" yang pertama untuk mengetahui bagaiman kepastian hukum bagi Usaha Mikro, Kecil, dan Menengah (UMKM) sebagai mitra Perusahaan Modal Ventura? Dan bagaiman tinjauan yuridis terhadap Pembiayaan Modal Ventura Syari'ah terhadap Usaha Mikro, Kecil, dan Menengah (UMKM) dengan sistem profit sharing ditinjau dari Hukum Islam?

Karakeristik UMKM sebagai Pasangan Usaha dari Perusahaan Modal Ventura memiliki karakteristik yang berbeda dengan karakteristik Pasangan Usaha lainnya, perbedaan inilah yang turut menentukan pola mana yang paling sesuai dengan dengan pembiayaan modal ventura, khususnya pembiayaan modal ventura syari'ah. 


\section{B. METODE PENELITIAN}

Penelitian hukum ini merupakan penelitian hukum normatif. Penelitian ini mendasarkan pada penelitian hukum yang dilakukan dengan pendekatan konseptual (conceptual approach). Objek kajian pendekatan konseptual (conceptualical approach) yaitu beranjak dari pandangan-pandangan dan doktrin-doktin yang berkembang di dalam ilmu hukum. Dengan mempelajari pandangan-pandangan dan doktrin-doktrin di dalam ilmu hukum, peneliti akan menemukan ide-ide yang melahirkan pengertian-pengertian hukum, konsep-konsep hukum, dan asas-asas hukum yang relevan dengan isu-isu yang dihadapi (Peter Mahmud Marzuki, 2009: 93).Oleh karena itu pengkajian yang dilakukan, hanyalah "terbatas" pada data sekunder yang diperoleh dari bahan kepustakaan atau literature yang mempunyai hubungan dengan objek yang diteliti. Adapaun analisis data yang digunakan yaitu analisis kualitatif.

\section{PEMBAHASAN}

Dalam Pasal 2 Peraturan Menteri Keuangan No. 8 /PMK.010/2012 Tentang Perusahaan Modal Ventura, kegiatan usaha modal ventura meliputi (1) Penyertaan saham (equity participation); (2) Penyertaan melalui pembelian obligasi konversi (quasi equity participation); dan (3) Pembiayaan berdasarkan pembagian atas hasil usaha (profit/revenue sharing).

Setiap pelaksanaan pembiayaan modal ventura harus diawali terlebih dahulu dengan perjanjian modal ventura. Sebagaimana menurut Fuady (1995: 167), Dokumen pokok yang paling penting sebagai bukti adanya kerja sama dalam usaha modal ventura adalah perjanjian modal ventura (venture capital agreement/shareholdel agreement). Perjanjian Modal ventura dilakukan antara Perusahaan Modal Ventura dan Perusahaan Pasangan Usaha sebagai mitra dalam pembiayaan modal ventura.

Perjanjian modal ventura yang paling banyak digunakan adalah pola perjanjian berdasarkan bagi hasil atas hasil usaha (profit sharing). Hal tersebut didukung dengan dikeluarkannya Peraturan Menteri Keuangan No. 18/PMK.010/2012 tentang Perusahaan 
Modal Ventura, Usaha Mikro, Kecil, dan Menengah (UMKM) telah mendapat perlindungan hukum untuk menjadi Perusahaan Pasangan Usaha dari Perusahaan Modal Ventura. Karena secara karakteristik bentuk usahanya, UMKM adalah usaha yang paling tepat dengan perjanjian bersasarkan bagi hasil (profit sharing)

Dari segi kuantitas UMKM jumlahnya lebih banyak dibandingkan Perusahaan Pasangan Usaha yang berbentuk Perseroan Terbatas, Koperasi, CV maupun Firma (Fa). Disamping itu prospek pengembangan UKMK sangat strategis untuk mendapatkan pembiayaan modal ventura dan pembinaan menejemen dari Perusahaan Modal Ventura.

Menurut Muhammad (2001: 22) Secara terminologi, profit sharing dalam kamus ekonomi diartikan pembagian laba. Secara definitif profit sharing diartikan "distribusi" beberapa bagian dari laba pada para pegawai dari suatu perusahaan. Dalam ajaran Islam, konsep profit sharing sering disebut bagi hasil. Konsep ini dengan mudah dijumpai dalam praktek masyarakat Islam pada masa Rasulullah dan Sahabat hingga masyarakat Islam saat ini (M. B. Hendrie Anto, 2003: 242). Dalam dunia pembiayaan, profit sharing sering disebut dengan istilah penyertaan secara tidak langsung (indirect investment) yaitu suatu penyertaan modal oleh perusahaan modal ventura pada perusahaan pasangan usaha tidak dalam bentuk modal saham (equity), tetapi dalam bentuk obligasi konversi (convertible bond) atau partisipasi terbatas/bagi hasil (profit sharing) (Sunaryo, 2008: 33).

Pembiayaan dalam islam juga mendukung modal ventura. Adapun jenis pembiayaan (Nurul Huda, 2010: 375-378) yang dianjurkan dalam Islam adalah:

\section{Musyarakah}

Jenis pembiayaan ini merupakan pencampuran dana dari pembiayaan musyarakah (modal ventura) dan dana dari pengusaha patnernya. kedua belah pihak menanggung rugi dan atau memperoleh keuntungan dari usaha yang mereka bentuk. Untung dan rugi yang mereka peroleh kedua belah pihak dinikmati secara bersama-sama sesuai dengan porsi yang ada dengan konsep profit (loss sharing). Hal ini sesuai dengan Firman Allah SWT: 


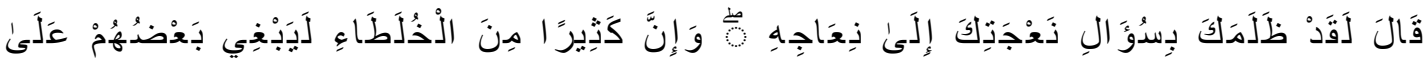

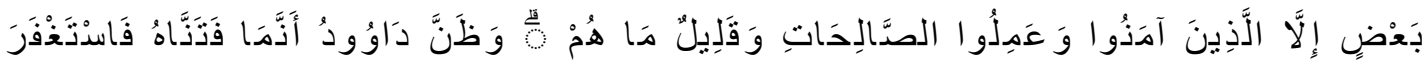

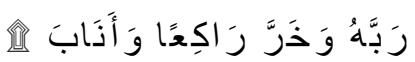

"Daud berkata: "sesungguhnya dia telah berbuat zalim kepadamu dengan meminta kambingmu itu untuk ditambahkan kepada kambingnya. Dan sesungguhnya kebanyakan dari orang-orang dari orang-orang yang berserikat itu sebagian mereka berbuat zalim kepada sebagian yang lain, kecuali orang-orang yang beriman dan mengerjakan amal saleh; dan amat sedikitlah mereka ini". Dan Daud mengetahui bahwa Kami mengujinya; maka ia meminta ampun kepada Tuhannya lalu menyungkur sujud dan bertaubat". (QS. Shaad/38:24).

Dan Hadist Nabi SAW:

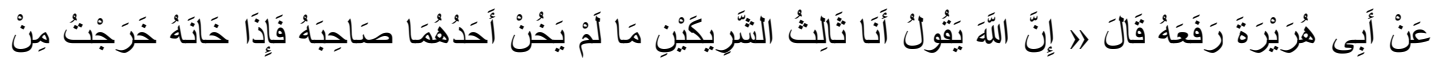

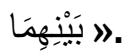

"Dari Abu Hurairah r.a, Allah berfirman: Aku adalah kongsi ketiga dari dua orag yang berkongsi, selama salah seorang kongsi tidak menghianati yang lainnya, apabila ia telah menghianatinya, maka aku keluar dari perkongsian itu". (H.R. Abu Daud 3385)

\section{Mudharabah}

Pembiayaan usaha yang dapat diselaraskan dengan dengan instrument obligasi. Perusahaan Pasangan Usaha memegang amanah dari Perusahaan Modal Ventura dimana modal yang ada merupakan titipan agar dimanfaatkan untuk memperoleh keuntungan. Hal ini sesuai dengan firman Allah SWT:

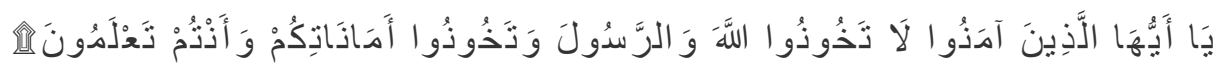

"Hai orang-orang yang beriman, janganlah kamu mengkhianati manah-amanah Allah dan Rasul (Muhammad) dan (juga) janganlah kamu mengkhianati amanatamanat yang dipercayakan kepadamu, sedang kamu mengetahui". (QS. AlAnfal/8:27)

Dan Hadits Nabi SAW: 


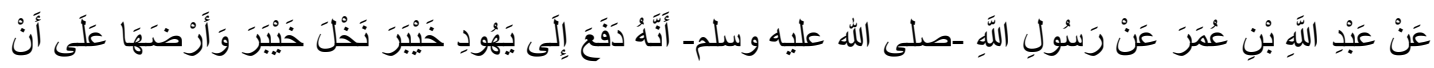

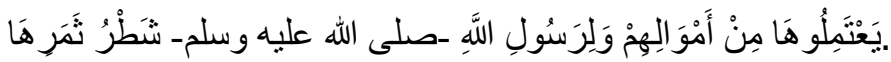

"Dari Abdullah bin Umar dari Rasulullah, bahwa Rasulullah menyerahkan kepada bangsa Yahudi Khaibar kebun kurma dan lading daerah Khaibar, agar mereka menggarapnya dengan biaya mereka sendiri, dengan perjanjian, Rasulullah mendapatkan separuh hasil penennya". (HR. Muslim 4048)

\section{Murabahah}

Pembiayaan Murabahan merupakan jual beli barang untuk keperluan investasi dan juga bahan baku yang digunakan untuk kepentingan modal kerja. Pembiayaan jenis ini dapat dilakukan apabila Perusahan Modal Ventura bernegosiasi dengan pihak pengusaha yang ingin membeli barang investasi dalam bentuk mesin. Hal ini didukung Firman Allah SWT:

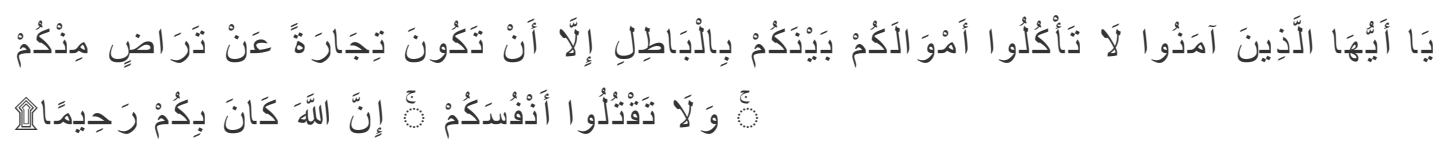

"Hai orang-orang yang beriman, janganlah kamu saling memakan harta sesamamu dengan jalan yang batil, kecuali dengan jalan perniagaan yang berlaku suka sama-suka diantara kamu. Dan janganlah kamu membunuh dirimu; sesungguhnya Allah maha penyayang kepadamu". (QS. Annisa': /4:29)

Dan Hadits Nabi SAW:

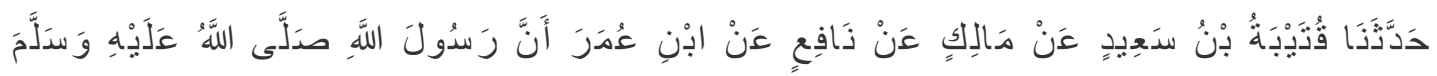
نَسَى عَنْ النَّجْشِ

"Telah menceritakan kepada kami Qutaibah bin Sa'id dari Malik dari nafi' dari Ibnu Umar, Rasulullah SAW melarang jual beli najasy (penipuan)". (H.R. Bukhori 6448)

Seiring dengan perkembangan modal ventura dari waktu ke waktu, penyelenggaraan modal ventura atau kegiatan usaha modal ventura mengalami perkembangan, hal ini ditandai dengan diterbitkannya Peraturan Otoritas Jasa Keuangan No. 35 /POJK.05/2015 Tentang Penyelenggaraan Usaha Perusahaan Modal Ventura. 
Menurut Pasal 2 Peraturan Otoritas Jasa Keuangan No. 35 /POJK.05/2005, Perusahaan Modal Ventura menyelenggarakan Usaha Modal Ventura yang meliputi:

(a) Penyertaan saham (equity participation);

(b) Penyertaan melalui pembelian obligasi konversi (quasi equity participation);

(c) Pembiayaan melalui pembelian surat utang yang diterbitkan Pasangan Usaha pada tahap rintisan awal (start-up) dan/atau pengembangan usaha; dan/atau;

(d) Pembiayaan usaha produktif.

Usaha Modal Ventura Syari'ah (UMVS) telah mendapat perlindungan hukum dalam peraturan perundang-undangan di Indonesia, hal ini sangat menggembirakan bagi pelaku bisnis di tanah air. Bahkan Peraturan Otoritas Jasa Keuangan No. 35 /POJK.05/2015 Tentang Penyelenggaraan Usaha Perusahaan Modal Ventura telah membuat definisi tentang UMVS, yaitu Usaha Modal Ventura Syari'ah yang selanjutnya disingkat UMVS adalah usaha pembiayaan melalui kegiatan investasi dan/atau pelayanan jasa yang dilakukan dalam jangka waktu tertentu dalam rangka pengembangan usaha pasangan usaha yang dilaksanakan berdasarkan prinsip syari'ah.

Subjek hukum dari usaha modal ventura syari'ah adalah Perusahaan Modal Ventura Syari'ah (PMVS) dan Pasangan Usaha (PU). Perusahaan Modal Ventura Syari'ah adalah badan usaha yang melakukan kegiatan Usaha Modal Ventura Syari'ah, pengelolaan dana ventura, dan kegiatan usaha lain dengan persetujuan Otoritas Jasa Keuangan yang seluruhnya dilaksanakan berdasarkan prinsif syari'ah. Bentuk badan usaha PMV atau PMVS menurut Peraturan Otoritas Jasa Keuangan No. 35 /POJK.05/2015 Tentang Penyelenggaraan Usaha Perusahaan Modal Ventura, yaitu dapat berbentuk Perseroan Terbatas, Koperasi, atau Perseroan Komanditer. 
Usaha Mikro, Kecil, dan Menengah (UMKM) sebagai Pasangan Usaha dari PMVS telah mendapat perlindungang hukum, sebagimana yang dimaksud dengan Pasangan Usaha (PU) adalah orang perseorangan atau perusahaan termasuk usaha mikro, kecil, dan menengah, dan koperasi yang menerima penyertaan modal dan/atau investasi berdasarkan prinsip bagi hasil dari PMV, PMVS, atau Unit Usaha Syari'ah (UUS). Bahkan PMV atau PMVS wajib memiliki kegiatan Usaha Modal Ventura atau Usaha Modal Ventura Syari'ah pada Pasangan Usaha dan/atau Debitur yang termasuk kategori usaha mikro, kecil, dan menengah, dan koperasi paling sedikit 5\% (lima persen) dari total kegiatan usaha.

Sebagai salah satu perbuatan hukum, modal ventura tentu harus diback up oleh sektor yuridis, agar dapat berlaku dalam lingkup pergaulan bisnis, salah satu diantaranya adalah prinsip kebebasan berkontrak. Seperti juga dengan lembaga financial lainnya seperti leasing, factoring, consumer finance, atau kartu kredit, maka modal ventura mempunyai dasar berupa kebebasan berkontrak vide Pasal 1338 ayat (1) KUH Perdata. Sebab, dalam peluncuran dana lewat modal ventura ini juga dimulai dari penandatanganan berbagai kontrak terlebih dahulu, termasuk kontak modal ventura itu sendiri (Munir Fuady, 2006:113).

PMVS dan UUS dalam menyelenggarakan Usaha Modal Ventura Syari'ah berupa investasi dengan pembiayaan berdasarkan prinsip bagi hasil dilakukan dalam bentuk penyediaan modal kepada Pasangan Usaha (PU) dengan jangka waktu tertentu untuk kegiatan usaha produktif dengan pembagian keuntungan sesuai dengan kesepakatan para pihak.

Dengan adanya asas kebebasan berkontrak (freedom of contract) berarti antara Perusahaan Modal Ventura Syari'ah dan UMKM bebas untuk mengadakan kontrak yang dituangkan dalam bentuk perjanjian tertulis. Namun kebebasan berkontrak tersebut tentulah bukan kebebasan yang mutlak, karena telah dibatasi oleh Undang-Undang yaitu berupa syarat syahnya suatu perjanjian. 
Untuk memenuhi apakah perjanjian modal ventura antara Perusahaan Modal Ventura dengan Pasangan Usaha (UMKM) harus memenuhi syarat syahnya perjanjian sebagaimana diatur dalam Pasal 1320 KUH Perdata:

(1) Sepakat mereka yang mengikatkan diri

Penjanjian modal ventura yang dibuat oleh Perusahaan Modal Ventura dan Pasangan Usaha (UMKM) maka kedua belah pihak harus saling sepakat.

(2) Kecakapan untuk membuat suatu perjanjian

Perusahaan Modal Ventura dan Pasangan Usaha (UMKM) sebagai subjek hukum harus cakap dalam membuat perjanjian. Adapun orang yang dianggap tidak cakap dalam membuat perjanjian menurut Pasal 1330 KUH Perdata, yaitu

- Orang-orang yang belum dewasa;

- Mereka yang ditaruh dibawah pengampuan;

- Wanita yang bersuami, (ketentuan ini dihapus dengan berlakunya UndangUndang No. 1 Tahun 1974 Tentang Perkawinan, karena Pasal 31 UndangUndang ini menentukan bahwa hak dan kedudukan suami istri adalah seimbang dan masing-masing berhak untuk melakukan perbuatan hukum).

(3) Suatu hal tertentu

Suatu hal tertentu yang menjadi objek dari perjanjian yang dibuat antara Perusahaan Modal Ventura dan Pasangan Usaha (UMKM) adalah Pembiayaan Modal Ventura.

(4) Suatu sebab yang halal

Maksudnya adalah perjanjian yang dibuat antara Perusahaan Modal Ventura dan Pasangan Usaha (UMKM) harus dibuat dengan alasan yang sesuai dengan hukum yang berlaku (legal). Tidak boleh membuat kontrak yang bertentangan dengan hukum. Dan isi perjanjian tidak boleh bertentangan dengan norma kesusilaan atau ketertiban umum (Pasal 1337 KUH Perdata).

Seluruh perjanjian kegiatan usaha antara PMV, PMVS, dan/atau UUS dengan Pasangan Usaha dan/atau Debitur wajib dibuat secara tertulis dan harus memenuhi 
ketentuan penyusunan perjanjian sebagaimana diatur diatur dalam Peraturan OJK mengenai perlindungan konsumen sektor jasa keuangan.

Dalam prespektif Hukum Islam, Pembiayaan Modal Ventura Syari'ah sebagai suatu bentuk kontrak modern tidak dapat terhindar dari akad yang membentuknya. Hal ini disebabkan karena dalam praktiknya, pembiayaan modal ventura melibatkan dua pihak yang terikat oleh perjanjian untuk melaksanakan kawajiban, yaitu antara Perusahaan Modal Ventura Syari'ah dengan Pasangan Usaha. Berkenaan dengan ini Allah SWT berfirman dalam QS. Al-Maidah [/5:1]

أبه

Artinya: "Hai orang-orang yang beriman, penuhilah akad-akad itu....." (QS. AlMaidah /5:1)

dalam melakukan perjanjian modal vetura syari'ah juga terikat dengan syarat yang disepakati antara Perusahaan Modal Ventura Syari'ah dengan Pasangan Usaha, berikut adalah Hadits tentang Perjanjian:

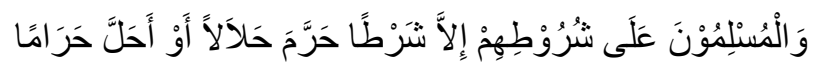

Artinya: "Orang-orang muslim itu terikat dengan syarat yang mereka sepakati, kecuali syarat yang mengharamkan yang halal atau menghalalkan yang haram." (HR. AtTurmudzi)

Hadits ini menjelaskan tentang prinsip umum dalam melakukan akad atau transaksi. Orang muslim dalam melakukan transaksinya tergantung oleh syarat yang mereka sepakati bersama antara kedua belah pihak, kecuali syarat yang mengharamkan yang halal atau menghalalkan yang haram. Dalam pembiayaan modal ventura syari'ah, akad atau transaksi antara Perusahaan modal Ventura Syari'ah dengan Pasangan Usaha harus berdasarkan syarat-syarat yang mereka tetapkan bersama. Kecuali syarat yang tidak sesuai dengan ketentuan syari'ah. 
Dalam melakukan kegiatan usaha PMVS dan UUS wajib memenuhi prinsip-prinsip sebagai berikut:

(a) Prinsip keadilan ('Adl);

"'Adl" adalah menempatkan sesuatu hanya pada tempatnya, dan memberi sesuatu hanya pada yang berhak serta memperlakukan sesuatu sesuai posisinya.

(b) Prinsip Keseimbangan (tawazun);

"Tawazun" adalah meliputi keseimbangan aspek material dan spiritual, aspek privat dan publik, sektor keuangan dan sektor riil, bisnis dan sosial, dan keseimbangan aspek pemanfaatan dan kelestarian.

(c) Prinsip Kemaslahatan (maslahah), dan;

"Maslahah" adalah merupakan segala bentuk kebaikan yang berdimensi duniawi dan ukhrawi, material dan spiritual serta individu dan kolektif serta harus memenuhi 3 (tiga) unsur yakni kepatuhan syari'ah (halal), bermanfaat dan membawa kebaikan (thoyib) dalam semua aspek secara keseluruhan yang tidak menimbulkan kemudharatan.

(d) Universalisme (alamiyah)

"Amaliyah" adalah dapat dilakukan oleh, dengan, dan untuk semua pihak yang berkepentingan (stakeholders) tanpa membedakan suku, agama, ras dan golongan, sesuai dengan semangat kerahmatan semesta (rahmatan lil alamin)

Dalam melakukan kegiatan usaha PMVS dan UUS wajib menghindari kegiatan yang mengandung:

(a) Gharar,

"Gharar" adalah transaksi yang objeknya tidak jelas, tidak dimiliki, tidak diketahui keberadaannya, atau tidak dapat diserahkan pada saat transaksi dilakukan kecuali diatur lain dalam syari'ah.

(b) Maysir,

"Maysir" adalah transaksi yang bersifat spekulatif (untung-untungan) yang tidak terkait langsung dengan produktifitas di sektor riil. 
(c) riba,

"Riba" adalah pemastian penambahan pendapatan secara tidak sah (bathil) antara lain dalam transaksi pertukaran barang sejenis yang tidak sama kualitas, kuantitas, dan waktu penyerahan (fadlh), atau dalam transaksi pinjammeminjam yang mempersyaratkan nasabah penerima fasilitas mengembalikan dana yang diterima melebihi pokok pinjaman karena berjalannya waktu (naisah)

(d) Zhulm, dan

"Zhulm" adalah transaksi yang menimbulkan ketidakadilan bagi pihak lainnya

(e) Risywah,

"Risywah" adalah tindakan suap dalam bentuk uang, fasilitas, atau bentuk lainnya yang melanggar hukum sebagai upaya mendapatkan fasilitas atau kemudahan dalam suatu transaksi.

(f) Objek haram

"Objek haram" adalah suatu barang atau jasa yang diharamkan dalam syari'ah.

Dari sisi perusahaan pasangan usaha atau mitra usaha, masuknya modal ventura sebagai salah satu alternatif sumber pembiayaan pada UMKM akan memberikan manfaat bagi UMKM yang bersangkutan diantaranya adalah sebagai berikut:

a. Kemungkinan berhasilnya usaha UMKM lebih besar, karena modal ventura yang diberikan dengan pola profit sharing disertai pula pendampingan manajemen.

b. Meningkatkan efisiensi pendistribusian produk dengan pemanfaatan teknologi pemasaran.

c. Meningkatkan kemampuan memperoleh keuntungan, karena modal ventura yang diberikan disertakan adanya kontrol manajemen yang orietasinya adalah memperoleh keuntungan dan mengembangkan usaha.

Manfaat yang diperoleh UMKM dari pembiayaan modal ventura tersebut didukung oleh peran tugas perusahaan modal ventura yang belum tentu bisa didapatkan dari lembaga perbankan dengan pinjaman kredit bank. Sebagai investor aktif, tentunya banyak tugas yang harus dilakukan oleh suatu perusahaan modal ventura. Namun pada prinsipnya, 
tugas-tugas tersebut dapat digolongkan ke dalam dua bagian besar, yaitu "pemantauan investasi" dan "peningkatan nilai tambah investasi". Pemantauan investasi pada prinsipnya dilakukan dengan menempatkan orang-orangnya pada manajemen perusahaan pasangan usaha. Dengan demikian investasi dapat langsung dipantau. Dan nilai tambah perusahaan pun dapat diawasi dan ditingkatkan (Munir Fuady: 2006: 144).

Secara lebih rinci, yang dilakukan perusahaan modal ventura dalam meningkatkan nilai tambah investasi, yang dapat dirasakan manfaatnya tidak saja oleh perusahaan pasangan usaha yang berbentuk PT, Koperasi, CV, ataupun Fa, juga dapat dirasakan manfaatnya oleh UMKM sebagai patner bisnis Perusahaan Modal Ventura, antara lain dapat disebutkan sebagai (Handowo Dipo, 1993: 158) berikut:

(a) Mencari, menginterview, memilih dan melakukan negosiasi dengan eksekutif professional.

(b) Marketing

(c) Mencari, memilih dan menegosiasi pihak pemasok bahan baku

(d) Melatih dan memberikan penyuluhan terhadap pendiri/pemilik perseroan atau staf manajemen lainnya.

(e) Mencari sumber dana lainnya

(f) Membina hubungan dengan calon pembeli saham lainnya.

(g) Memilih penjamin emisi dan profesi pasar modal yang tepat dalam rangka go public.

Perihal pendampingan (manajemen) bagi UMKM dari Perusahaan Modal Ventura juga ditegaskan dalam Pasal 2 ayat (4) Peraturan Otoritas Jasa Keuangan No. 35 /POJK.05/2015 Tentang Penyelenggaraan Usaha Perusahaan Modal Ventura;

"Kegiatan Usaha Modal Ventura sebagiamana dimaksud dalam Ayat (1) dapat disertai dengan pendampingan kepada Pasangan Usaha dan/atau Debitur" 
Pendampingan bagi UMKM dari Perusahaan Modal Ventura untuk menyertai kegiatan usaha modal ventura harus disepakati oleh kedua belah pihak sekiranya dibutuhkan oleh Pasangan Usaha dan/atau Debitur

Investasi yang dilakukan oleh Perusahaan Modal Ventura tidaklah berjalan selamanya. Sebagaimana dinyatakan dalam Pasal 4 ayat (2) Keputusan Menteri Keuangan No. 1251/KMK.013/1988, bahwa penyertaan modal dalam setiap perusahaan pasangan usaha bersifat sementara dan tidak boleh melebihi jangka waktu 10 tahun. Dengan demikian, dalam usaha modal ventura diharuskan adanya divestasi atas modal yang telah ditanam pada perusahaan pasangan usaha. Divestasi ini merupakan kewajiban yang harus dilakukan oleh perusahaan modal ventura setelah jangka waktu yang disepakati atau ditentukan berakhir.

\section{PENUTUP}

Sejak diterbitkannya Peraturan Menteri Keuangan No. 18/PMK.010/2012 tentang Perusahaan Modal Ventura, UMKM telah mendapat perlindungan hukum untuk menjadi subjek hukum dari kerjasama pembiayaan modal ventura. Dan dengan diterbitkannya Peraturan Otoritas Jasa Keuangan No. 35 /P0JK.05/2015 Tentang Penyelenggaraan Usaha Perusahaan Modal Ventura, UMKM telah mendapat perlindungan hukum untuk menjadi Pasangan Usaha (PU) bagi Perusahan Modal Ventura (PMV) maupun Perusahaan Modal Ventura Syari'ah (PMVS).

Usaha Mikro, Kecil, dan Menengah (UMKM) mendapatkan pembiayaan dengan pola perhitungan profit sharing dalam perakteknya dapat mengikuti pola pembiayaan islam yaitu Musyarakah, Mudharabah, dan Murabahah. Dan Pembiayaan Modal Ventura Syari'ah (PMVS) telah mendapatkan perlindungan hukum dari hukum positif di Indonesia untuk melakukan pembiayaan berdasarkan prinsip bagi hasil (profit sharing). Setiap penyelenggaraan kegiatan usaha PMVS dan UUS wajib memenuhi prinsip keadilan, keseimbangan, kemaslahatan, dan universalisme.

\section{DAFTAR PUSTAKA}


Abdulkadir Muhammad. 2004. Lembaga Keuangan dan Pembiayaan. Bandung: Penerbit PT. Citra Adiya Bakti.

Ahmad Muliadi. 2013. Hukum Lembaga Pembiayaan. Jakarta: Akademia Permata.

Handowo Dipo. 1993. Sukses Memperoleh Dana. Jakarta: Grafiti.

Hasan Ali. 2004. Asuransi dalam Perspektif Hukum Islam (Suatu Tinjauan Analisis Historis, Teoritis, \& Praktis). Jakarta: Prenada Media.

M. B. Hendrie Anto. 2003. Pengantar Ekonomi Mikro Islami. Yogyakarta: Ekonisia.

Muhammad. 2001. Teknik Perhitungan Bagi Hasil di Bank Syari'ah. Yogyakarta: UII Pers.

Munir Fuady. 1995. Hukum tentang Pembiayaan dalam Teori dan Praktik (Leasing, Factoring, Modal Ventura, Pembiayaan Konsumen, Kartu Kredit). Bandung: Citra Aditya Bakti.

Munir Fuady. 2006. Hukum tentang Pembiayaan (Dalam Teori dan Praktek). Bandung: Penerbit PT. Citra Aditya Bakti.

Nurul Huda, Mohammad Haykal. 2010. Lembaga Keuangan Islam: Tinjauan Teoritis dan Praktis. Jakarta: Kencana.

Salim HS, Erlies Septiana Nurbani. 2013. Penerapan Teori Hukum Pada Penelitian Tesis dan disertasi. Jakarta: PT. RajaGrafindo Persada.

Peter Mahmud Marzuki. 2009. Penelitian Hukum, Jakarta: Kencana.

R. Subekti, R. Tjitrosudibio. 2005. Kitab Undang-Undang Hukum Perdata. Jakarta: PT. Pradnya Paramita.

Sunaryo. 2008. Hukum Lembaga Pembiayaan. Jakarta: Penerbit Sinar Grafika.

\section{Peraturan Perundang-undangan}

Peraturan Menteri Keuangan No. 8 /PMK.010/ 2012 Tentang Perusahaan Modal Ventura

Keputusan Menteri Keuangan No. 1251/KMK.013/1988 Tentang Ketentuan dan Tata Cara Pelaksanaan Lembaga Pembiayaan

Peraturan Otoritas Jasa Keuangan No. 35 /POJK.05/2015 Tentang Penyelenggaraan Usaha Perusahaan Modal Ventura 
Peraturan Otoritas Jasa Keuangan No. 1 /POJK.07/2014 Tentang Lembaga Alternatif Penyelesaian Sengketa di Sektor Jasa Keuangan

Peraturan Otoritas Jasa Keuangan No. 1 /POJK.07/2013 Tentang Perlindungan Konsumen Sektor Jasa Keuangan

Undang-Undang No. 21 Tahun 2011 Tentang Otoritas Jasa Keungan

Undang-Undang No. 20 Tahun 2008 Tentang Usaha, Mikro, Kecil, dan Menengah 